\title{
Streptomyces caviscabies sp. nov., from Deep-Pitted Lesions in Potatoes in Québec, Canada
}

\author{
CLAUDIA GOYER, ESTHER FAUCHER, AND CAROLE BEAULIEU* \\ Groupe de Recherche en Biologie des Actinomycètes, Département de Biologie, \\ Université de Sherbrooke, Sherbrooke, Québec, Canada, J1K 2R1
}

\begin{abstract}
Eight deep-pitted-scab-inducing streptomycetes isolated from potato lesions in Québec (Canada) were phenotypically compared with representative strains of the principal plant-pathogenic Streptomyces species. These eight strains could be distinguished from representatives of Streptomyces scabies, Streptomyces aureofaciens, Streptomyces ipomoeae, and Streptomyces acidiscabies on the basis of their morphological or physiological properties. They were characterized by a gold mycelium on yeast-malt extract medium and a white mass of spores borne in flexuous chains. The spores of these organisms were cylindrical and smooth. Their cell walls contained the LL-diaminopimelic acid isomer, and their DNA guanine-plus-cytosine content was 71 mol\%. The strains which we studied did not produce melanin. All of the strains grew on proline or methionine as a sole nitrogen source and utilized raffinose as a sole carbon source. Bacterial growth was inhibited at pH 4.5. The levels of DNA relatedness between the deep-pitted-scab-inducing strains and strains of the other plant-pathogenic Streptomyces species were low. We place these deep-pitted-scab-inducing strains in a new bacterial species, for which we propose the name Streptomyces caviscabies. The type strain of this species is strain ATCC 51928.
\end{abstract}

Several Streptomyces species are causal agents of potato scab, but Streptomyces scabies is the predominant pathogen. $S$. scabies induces shallow, raised, or deep-pitted corky lesions on tubers and expanded tap roots. In 1989 this species was revived and redefined by Lambert and Loria (12), who characterized $S$. scabies as a species which has smooth gray spores borne in spiral chains, produces melanin, and utilizes all of the diagnostic sugars recommended by the International Streptomyces Project to identify Streptomyces species (18). Paradis et al. (15) divided the $S$. scabies strains in Québec into two genetic groups that exhibited relatively low levels of DNA relatedness (between 21 and $60 \%$ ) (15). Even though $S$. scabies can occasionally induce deep-pitted scab depending on the interaction among cultivar, environmental conditions, and virulence of the isolate, in two independent studies workers identified other Streptomyces species as the predominant causal agents of deeppitted scab of potatoes $(1,5)$. Archuleta and Easton (1) suggested that most cases of deep-pitted scab in the state of Washington should not be attributed to $S$. scabies but rather should be attributed to four other Streptomyces species (Streptomyces diastatochromogenes, Streptomyces atroolivaceus, Streptomyces lydicus, and Streptomyces resistomyficus). Unfortunately, this suggestion has never been confirmed.

Recently, a group of streptomycetes isolated from potato scab lesions in Québec was characterized $(5,6)$. This group of actinomycetes was associated with deep-pitted scab (Fig. 1) and was most commonly isolated from tubers grown in irrigated soil. The members of this group exhibited numerous traits that were not characteristic of $S$. scabies; for example, they produced white spores borne in flexuous chains, they did not produce a melanoid pigment, and they were resistant to streptomycin. In addition, these organisms could not be identified as members of another important potato scab-inducing species, Streptomyces acidiscabies, on the basis of their physiological properties $(5,11)$. Phenotypic characterization, a fatty

\footnotetext{
* Corresponding author. Mailing address: Département de Biologie, Université de Sherbrooke, 2500 Blv. Université, Sherbrooke (Québec), Canada, J1K 2R1. Phone: (819) 821 7997. Fax: (819) 821 8049. Electronic mail address: C.BEAULI@COURRIER.USHERB.CA.
}

acid analysis, and whole-cell protein electrophoresis revealed that these plant-pathogenic bacteria formed a relatively homogeneous group (5). A numerical analysis (5) showed that these deep-pitted-scab-inducing strains shared numerous phenotypic traits (level of similarity, 75.8\%) with strains belonging to the Streptomyces albidoflavus cluster of Williams et al. (22).

$S$. scabies, $S$. acidiscabies, and Streptomyces ipomoeae, the causal agent of sweet potato pox, produce thaxtomins, a group of phytotoxins that appear to play an important role in the phytopathogenicity of streptomycetes $(9,10)$. S. scabies and $S$. acidiscabies strains produce thaxtomins on potato tubers (10) and also in some culture media made out of oatmeal $(2,14)$. In contrast to $S$. scabies and $S$. acidiscabies (14) and like $S$. ipomoeae (9), the strains from Québec that cause deep-pitted scab do not produce thaxtomins in oatmeal media. However, they do produce thaxtomins in media made out of potato or sweet potato peels (7).

The purposes of this work were (i) to compare the phenotypic traits of the deep-pitted-scab-inducing bacteria from Québec with the phenotypic traits of the principal phytopathogenic streptomycetes and $S$. albidoflavus and (ii) to determine the levels of DNA complementarity between the deep-pittedscab-inducing strains and representatives of other Streptomyces species. On the basis of our results we propose that the plantpathogenic bacteria from Québec should be placed in a new species, Streptomyces caviscabies.

\section{MATERIALS AND METHODS}

Strains. We characterized the following eight deep-pitted-scab-inducing strains from Québec (Canada): EF-83, EF-86, EF-87 ${ }^{\mathrm{T}}$ (T = type strain), EF-88, EF-92, EF-98, EF-104, and EF-123 (Table 1). These deep-pitted-scab-inducing strains were compared phenotypically with representative strains of other phytopathogenic Streptomyces species (including $S$. acidiscabies [11], S. ipomoeae [13], $S$. scabies [12], and Streptomyces aureofaciens [4]), with $S$. albidoflavus ATCC $25422^{\mathrm{T}}$, and with strains belonging to $S$. albidoflavus cluster 1 of Williams et al. (22), (Table 2).

Phenotypic characterization. Colony color and spore color were observed after 10 days of growth at $30^{\circ} \mathrm{C}$ on yeast-malt extract (YME) medium (16). Spore ornamentation and spore chain morphology were determined by scanning electron microscopy as follows. Sporulating colonies were fixed in situ in $2 \%$ glutar-

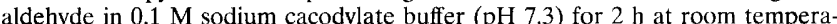
ture. Small pieces of agar were then cut out with a razor blade and postfixed in $2 \%$ osmium tetroxide in the same cacodylate buffer for $2 \mathrm{~h}$ at room temperature. The pieces were then dehydrated in a graded ethanol series, critical point dried 
TABLE 1. Bacterial strains used in this study

\begin{tabular}{|c|c|c|}
\hline Strain & Potato cultivar & Geographical origin \\
\hline \multicolumn{3}{|l|}{ S. caviscabies strains } \\
\hline EF-83 & Superior & Saint-Ambroise, Québec, Canada \\
\hline $\mathrm{EF}-86$ & Trent & Saint-Ambroise, Québec, Canada ${ }^{a}$ \\
\hline $\mathrm{EF}-87^{\mathrm{T}}$ & Trent & Saint-Ambroise, Québec, Canada ${ }^{a}$ \\
\hline EF-88 & Trent & Saint-Ambroise, Québec, Canada ${ }^{a}$ \\
\hline EF-92 & Trent & Saint-Ambroise, Québec, Canada ${ }^{b}$ \\
\hline EF-98 & Trent & Saint-Ambroise, Québec, Canada ${ }^{b}$ \\
\hline EF-104 & Norchip & Saint-Arsène, Québec, Canada \\
\hline $\mathrm{EF}-123$ & Superior & Inverness, Québec, Canada \\
\hline \multicolumn{3}{|l|}{ S. acidiscabies strains } \\
\hline ATCC $49003^{T}$ & Katahdin & Central New York \\
\hline EF-9 & Unknown & North Hatley, Québec, Canada \\
\hline EF-12 & Kennebec & Rivière-du-Loup, Québec, Canada \\
\hline EF-81 & Trent & Saint-Ambroise, Québec, Canada \\
\hline S. albidoflavus ATCC $25422^{\mathrm{T}}$ & $\mathrm{NA}^{c}$ & Unknown \\
\hline \multicolumn{3}{|l|}{ S. aureofaciens strains } \\
\hline EF-31 & Kennebec & Les Buissons, Québec, Canada \\
\hline EF-38 & Acadia Russet & Les Buissons, Québec, Canada \\
\hline EF-42 & Atlantic & Les Buissons, Québec, Canada \\
\hline EF-62 & Atlantic & Les Buissons, Québec, Canada \\
\hline EF-69 & Superior & La Pocatière, Québec, Canada \\
\hline EF-70 & Norland & La Pocatière, Québec, Canada \\
\hline EF-74 & Kennebec & La Pocatière, Québec, Canada \\
\hline EF-111 & Kennebec & Bonaventure, Québec, Canada \\
\hline EF-112 & Kennebec & Bonaventure, Québec, Canada \\
\hline EF-115 & Unknown & Inverness, Québec, Canada \\
\hline $\mathrm{EF}-120$ & Unknown & Péribonka, Québec, Canada \\
\hline EF-126 & Kennebec & Saint-Ambroise, Québec, Canada \\
\hline EF-130 & Unknown & Péribonka, Québec, Canada \\
\hline EF-138 & Belmont & Saint-Léonard-d'Aston, Québec, Canada \\
\hline S. ipomoeae $91-3$ & NA & Unknown \\
\hline \multicolumn{3}{|l|}{ S. scabies strains } \\
\hline EF-5 & Unknown & Rivière-du-Loup, Québec, Canada \\
\hline EF-35 & Kennebec & Notre-Dame-de-la-Paix, Québec, Canada \\
\hline EF-46 & F84002 & Les Buissons, Québec, Canada \\
\hline EF-49 & Unknown & Rivière du Loup, Québec, Canada \\
\hline EF-54 & Acadia Russet & Les Buissons, Québec, Canada \\
\hline EF-63 & Acadia Russet & Les Buissons, Québec, Canada \\
\hline EF-64 & Kennebec & Notre-Dame-de-la-Paix, Québec, Canada \\
\hline EF-68 & Kennebec & North Hatley, Québec, Canada \\
\hline EF-84 & Superior & Saint-Ambroise, Québec, Canada \\
\hline ATCC $49173^{\mathrm{T}}$ & Unknown & Maine \\
\hline
\end{tabular}

${ }^{a}$ Strains EF-86, EF- $87^{\mathrm{T}}$, and EF-88 were isolated from different tubers that came from the same field.

${ }^{b}$ Strains EF-92 and EF-98 were isolated from different tubers that came from the same field.

c NA, not applicable.

by using liquid $\mathrm{CO}_{2}$, and evaporation coated with gold-palladium at $10 \mathrm{~mA}$ and $4 \times 10^{-6} \mathrm{~Pa}$ with an Edwards sputter coater. The colonies were examined with a JEOL model $840 \mathrm{~A}$ scanning electron microscope.

Sugar utilization was determined in a minimal medium containing (per liter) $2.64 \mathrm{~g}$ of $\left(\mathrm{NH}_{4}\right)_{2} \mathrm{SO}_{4}, 2.38 \mathrm{~g}$ of $\mathrm{KH}_{2} \mathrm{PO}_{4}, 5.65 \mathrm{~g}$ of $\mathrm{K}_{2} \mathrm{HPO}_{4} \cdot 3 \mathrm{H}_{2} \mathrm{O}, 1 \mathrm{~g}$ of $\mathrm{MgSO}_{4} \cdot 7 \mathrm{H}_{2} \mathrm{O}, 6.4 \mathrm{mg}$ of $\mathrm{CuSO}_{4} \cdot 5 \mathrm{H}_{2} \mathrm{O}, 1.1 \mathrm{mg}$ of $\mathrm{FeSO}_{4} \cdot 7 \mathrm{H}_{2} \mathrm{O}, 7.9 \mathrm{mg}$ of $\mathrm{MnCl}_{2} \cdot \mathrm{H}_{2} \mathrm{O}, 1.5 \mathrm{~g}$ of $\mathrm{ZnSO}_{4} \cdot 7 \mathrm{H}_{2} \mathrm{O}$, and $15 \mathrm{~g}$ of agar. Sugars were added to this medium at a final concentration of $1 \%$ (wt/vol) (12). The basal medium used to test utilization of different nitrogen sources contained (per liter) $10 \mathrm{~g}$ of glucose, $5 \mathrm{~g}$ of $\mathrm{MgSO}_{4} \cdot 7 \mathrm{H}_{2} \mathrm{O}, 5 \mathrm{~g}$ of $\mathrm{NaCl}, 1 \mathrm{~g}$ of $\mathrm{K}_{2} \mathrm{HPO}_{4}, 10 \mathrm{mg}$ of $\mathrm{FeSO}_{4}$. $7 \mathrm{H}_{2} \mathrm{O}$, and $15 \mathrm{~g}$ of agar. Amino acids $(1 \mathrm{~g} / \mathrm{liter})$ were added to the basal medium as sole nitrogen sources. Growth was scored after 7 days of incubation at $30^{\circ} \mathrm{C}$ (12).

Tests to evaluate the ability of the strains to hydrolyze xylan and arbutin were carried out as described by Lambert and Loria (12). Utilization of polygalacturonic acid was determined on a medium containing (per liter) $5 \mathrm{~g}$ of polygalacturonic acid, $6 \mathrm{~g}$ of $\mathrm{Na}_{2} \mathrm{HPO}_{4}, 2 \mathrm{~g}$ of $\left(\mathrm{NH}_{4}\right)_{2} \mathrm{SO}_{4}, 4 \mathrm{~g}$ of $\mathrm{KH}_{2} \mathrm{PO}_{4}, 2 \mathrm{~g}$ of $\mathrm{MgSO}_{4} \cdot 7 \mathrm{H}_{2} \mathrm{O}, 6.4 \mathrm{mg}$ of $\mathrm{CuSO}_{4} \cdot 5 \mathrm{H}_{2} \mathrm{O}, 1 \mathrm{~g}$ of yeast extract, $1 \mathrm{mg}$ of $\mathrm{FeSO}_{4} \cdot$ $7 \mathrm{H}_{2} \mathrm{O}, 1 \mathrm{mg}$ of $\mathrm{CaCl}_{2}$ and $10 \mathrm{~g}$ of agar (22).

The ability of bacteria to grow at $\mathrm{pH} 4.5$ was tested on YME medium (16) at $30^{\circ} \mathrm{C}$. The inhibitory effects of $\mathrm{NaCl}(4,7,10$, and $13 \%)$, thallous acetate $(10$ and $100 \mu \mathrm{g} / \mathrm{ml})$, crystal violet $(0.5 \mu \mathrm{g} / \mathrm{ml})$, phenol $(0.1 \%)$, penicillin $\mathrm{G}(10 \mathrm{IU} / \mathrm{ml})$ oleandomycin $(100 \mu \mathrm{g} / \mathrm{ml})$, and streptomycin sulfate $(20 \mu \mathrm{g} / \mathrm{ml})$ on bacterial growth were determined on Bennett medium modified as proposed by Lambert and Loria (12). Production of melanoid pigment was detected on a peptone-yeast extract-iron agar (PYI) (18).

A diaminopimelic acid analysis was carried out by using the procedure of Becker et al. (3). Isomers were separated by thin-layer chromatography as described by Staneck and Roberts (20).

Genetic characterization. Procedure 3 of Hopwood et al. (8) was used to isolate total DNAs from Streptomyces strains. After genomic DNA was dialyzed against $0.1 \times \mathrm{SSC}(17)(1 \times \mathrm{SSC}$ is $0.15 \mathrm{M} \mathrm{NaCl}$ plus $0.015 \mathrm{M}$ sodium citrate $)$ the $\mathrm{G}+\mathrm{C}$ content of the genome was determined by the method of Ulitzur (21) by using salmon sperm DNA as the standard. DNA-DNA hybridization studies were performed as described by Stall et al. (19), as modified by Paradis et al. (15).

\section{RESULTS}

Phenotypic characterization of the deep-pitted-scab-inducing bacteria. The eight deep-pitted-scab-inducing streptomycetes which we studied were characterized by a gold to light brown mycelium on YME medium. The aerial mycelium contained a white mass of spores borne in flexuous chains. The spores were cylindrical, smooth, 0.87 to $1.08 \mu \mathrm{m}$ long, and 0.5 to $0.63 \mu \mathrm{m}$ in diameter (Fig. 2). These strains did not produce 
TABLE 2. Phenotypic comparison of strains of the plant-pathogenic species $S$. caviscabies, other plant-pathogenic species, and $S$. albidoflavus (cluster 1 of Williams et al.)

\begin{tabular}{|c|c|c|c|c|c|c|}
\hline Characteristic & $\begin{array}{l}\text { S. caviscabies } \\
\text { strains }^{a}\end{array}$ & $\begin{array}{l}\text { S. acidiscabies } \\
\text { strains }^{b}\end{array}$ & $\begin{array}{l}\text { S. albidoflavus } \\
\text { strains }^{c}\end{array}$ & $\begin{array}{l}\text { S. aureofaciens } \\
\text { strains }^{d}\end{array}$ & $\begin{array}{c}\text { S. ipomoeae } \\
91-3\end{array}$ & $\begin{array}{l}\text { S. scabies } \\
\text { strains }^{e}\end{array}$ \\
\hline Colony color on YME medium & Gold to light brown & Gold to light brown & Gold to light brown & Bright yellow & Gold & Tan to brown \\
\hline Spore color & White & White & Yellow-brown & Gray & Blue & Grey \\
\hline Spore ornamentation & Smooth & Smooth & Smooth & Smooth & Smooth & Smooth \\
\hline Spore chain morphology & Flexuous & Flexuous & Rectiflexuous & Flexuous & Spiral & Spiral \\
\hline $\begin{array}{l}\text { Melanin production on PYI } \\
\text { medium }\end{array}$ & $-f$ & - & - & - & - & + \\
\hline Production of diffusible pigment & $\mathrm{V}$ & + & - & - & + & - \\
\hline \multicolumn{7}{|l|}{ Utilization of carbon sources } \\
\hline L-Arabinose & - & + & V & + & + & + \\
\hline D-Fructose & - & + & + & + & + & + \\
\hline D-Mannitol & - & $\mathrm{V}$ & + & + & + & + \\
\hline Raffinose & + & $\mathrm{V}$ & $\mathrm{V}$ & + & + & $\mathrm{V}$ \\
\hline Rhamnose & - & + & V & + & + & $\mathrm{V}$ \\
\hline Sucrose & - & + & $\mathrm{V}$ & + & + & $\mathrm{V}$ \\
\hline D-Xylose & - & + & + & + & + & $\mathrm{V}$ \\
\hline \multicolumn{7}{|l|}{ Utilization of nitrogen sources } \\
\hline L-Proline & + & + & $\mathrm{V}$ & + & + & + \\
\hline L-Methionine & + & + & $\mathrm{V}$ & + & + & $\mathrm{V}$ \\
\hline \multicolumn{7}{|l|}{ Hydrolysis of: } \\
\hline Arbutin & - & - & t & $\mathrm{V}$ & + & $\mathrm{V}$ \\
\hline Polygalacturonic acid & - & - & $\mathrm{V}$ & - & + & $\mathrm{V}$ \\
\hline Xylan & + & + & - & $\mathrm{V}$ & - & $\mathrm{V}$ \\
\hline Growth at $\mathrm{pH} 4.5$ & - & + & - & - & + & - \\
\hline \multicolumn{7}{|l|}{ Growth in the presence of: } \\
\hline $\mathrm{NaCl}(4 \%)$ & + & $\mathrm{V}$ & + & + & + & $\mathrm{V}$ \\
\hline $\mathrm{NaCl}(7 \%)$ & $\mathrm{V}$ & - & $\mathrm{V}$ & - & - & - \\
\hline $\mathrm{NaCl}(10 \%)$ & - & - & $\mathrm{V}$ & - & - & - \\
\hline $\mathrm{NaCl}(13 \%)$ & - & - & - & - & - & - \\
\hline Thallous acetate $(10 \mu \mathrm{g} / \mathrm{ml})$ & + & $\mathrm{V}$ & + & - & - & - \\
\hline Thallous acetate $(100 \mu \mathrm{g} / \mathrm{ml})$ & V & - & - & - & - & - \\
\hline Crystal violet $(0.5 \mu \mathrm{g} / \mathrm{ml})$ & $\mathrm{V}$ & $\mathrm{V}$ & $\mathrm{V}$ & - & + & $\mathrm{V}$ \\
\hline Phenol $(0.1 \%)$ & + & V & V & V & + & $\mathrm{V}$ \\
\hline Penicillin $(10 \mathrm{IU} / \mathrm{ml})$ & + & + & $\mathrm{V}$ & + & + & + \\
\hline Oleandomycin $(100 \mu \mathrm{g} / \mathrm{ml})$ & $\mathrm{V}$ & - & $\mathrm{V}$ & V & - & $\mathrm{V}$ \\
\hline Streptomycin $(20 \mu \mathrm{g} / \mathrm{ml})$ & + & + & $\mathrm{V}$ & - & + & - \\
\hline
\end{tabular}

${ }^{a}$ Strains EF-83, EF-86, EF-87 ${ }^{\mathrm{T}}$, EF-88, EF-92, EF-98, EF-104, and EF-123 were studied.

${ }^{b}$ Strains EF-8, EF-12, EF-81, and ATCC $49003^{\mathrm{T}}$ were studied. On the basis of the morphological and physiological properties proposed by Lambert and Loria (11), the level of similarity between the strains from Québec and the American strains was $88 \%$.

${ }^{c}$ Data for cluster 1 strains from reference 22.

${ }^{d}$ Strains EF-31, EF-38, EF-41, EF-42, EF-62, EF-69, EF-70, EF-74, EF-111, EF-112, EF-115, EF-120, EF-126, EF-130, and EF-138 were studied.

${ }^{e}$ Strains EF-5, EF-35, EF-46, EF-49, EF-54, EF-63, EF-64, EF-68, and EF-84 were studied. On the basis of the morphological and physiological properties proposed by Lambert and Loria (12), the level of similarity between the strains from Québec and the American strains was $80 \%$.

$f_{-}$, negative; + , positive; $\mathrm{V}$, between 20 and $90 \%$ of the strains were positive.

melanin. All of the strains grew on proline or methionine as a sole nitrogen source and hydrolyzed xylan but no polygalacturonic acid and arbutin. Raffinose was the only International Streptomyces Project sugar utilized. Most strains grew in the presence of $4 \% \mathrm{NaCl}$ but not in the presence of an $\mathrm{NaCl}$ concentration of $7 \%$ or higher. All of the strains grew in the presence of $0.1 \%$ phenol, $10 \mathrm{IU}$ of penicillin per $\mathrm{ml}, 10 \mu \mathrm{g}$ of thallous acetate per ml, and $20 \mu \mathrm{g}$ of streptomycin sulfate per $\mathrm{ml}$. Bacterial growth was inhibited at $\mathrm{pH} 4.5$ on YME medium. Some strains produced a diffusible pigment on YME medium. Strains EF-92 and EF-98 produced a red pigment, whereas strain EF-104 produced a yellow pigment (Table 2). The cell walls of the deep-pitted-scab-inducing strains contained LLdiaminopimelic acid.

Genetic characterization. DNA from deep-pitted-scab-inducing strain EF-87 ${ }^{\mathrm{T}}$ was hybridized with DNAs from the seven other deep-pitted-scab-inducing strains characterized in this study. The levels of relatedness between strain EF- $87^{\mathrm{T}}$ DNA and the DNAs of the other deep-pitted-scab-inducing strains ranged from 73 to $100 \%$ (Table 3). The levels of relat- edness between the genomic DNA of deep-pitted-scab-inducing strain EF-87 $7^{\mathrm{T}}$ and the genomic DNAs of representatives of $S$. acidiscabies, $S$. aureofaciens, $S$. ipomoeae, and $S$. scabies were low (between 12 and 33\%). Strain EF-87 $7^{\mathrm{T}}$ also differed genetically from $S$. albidoflavus ATCC $25422^{\mathrm{T}}$ (level of DNA relatedness, 17\%). The guanine-plus-cytosine $(\mathrm{G}+\mathrm{C})$ content of strain EF-8 $87^{\mathrm{T}}$ DNA was $71 \pm 3 \mathrm{~mol} \%$.

\section{DISCUSSION}

In a previous study, in which numerical analysis was used to compare the deep-pitted-scab-inducing strains with members of the Streptomyces clusters defined by Williams et al. (22), Faucher et al. established that the level of similarity between the deep-pitted-scab-inducing strains and strains belonging to cluster 1 of Williams et al. (S. albidoflavus) was relatively high $(75.8 \%)$ (5). However, according to the criteria of Williams et al. (22), this level of similarity is not high enough to classify these two groups in the same cluster. The results of the DNADNA hybridization study which we conducted also confirmed 


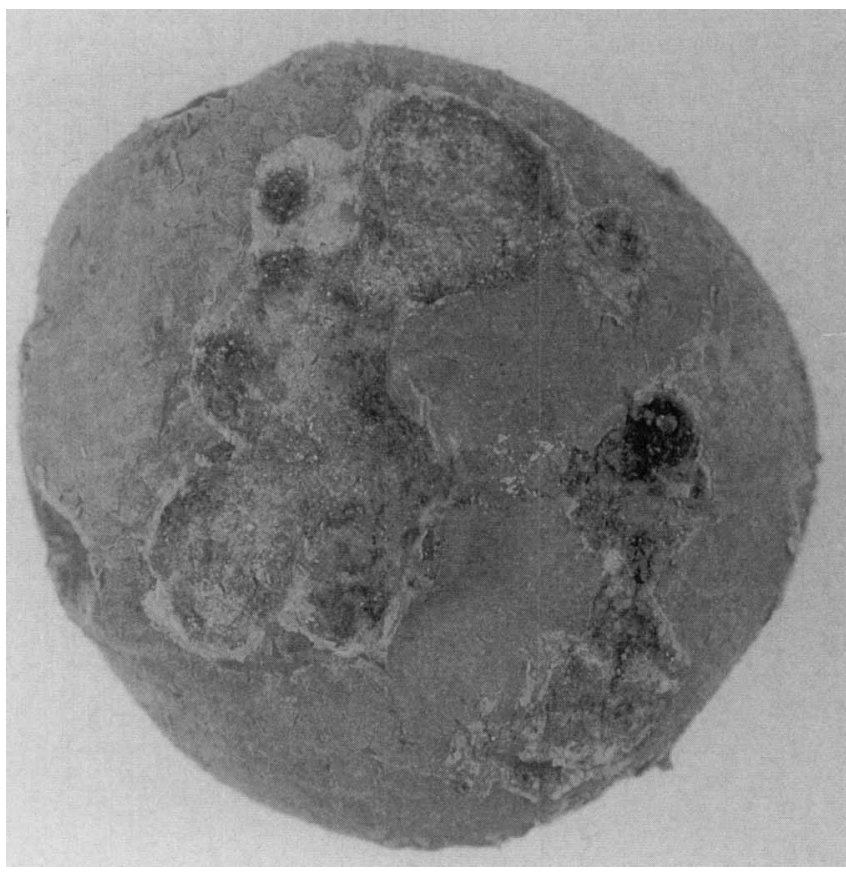

FIG. 1. Typical deep-pitted scab lesions on a potato tuber. Note the presence of the white Streptomyces spores inside the lesions.

that these two groups of strains should not be included in the same species. Indeed, the level of complementarity between $S$. albidoflavus ATCC $25422^{\mathrm{T}}$ DNA and DNA from deep-pittedscab-inducing strain $\mathrm{EF}-87^{\mathrm{T}}$ was only $17 \%$.

The deep-pitted-scab-inducing strains also differ from other phytopathogenic streptomycetes. The levels of DNA relatedness between the deep-pitted-scab-inducing strains and other plant-pathogenic streptomycetes did not exceed $33 \%$ (Table 3). The deep-pitted-scab-inducing organisms also differed mor-

TABLE 3. Levels of relatedness between $S$. caviscabies EF-87 DNA and DNAs of other $S$. caviscabies strains and strains belonging to other Streptomyces species

Strain
S. caviscabies strains $\begin{gathered}\begin{array}{c}\% \text { Hybridization } \\ \text { with DNA from } \\ \text { strain EF-87 }\end{array} \\ \text { EF-83 }\end{gathered}$

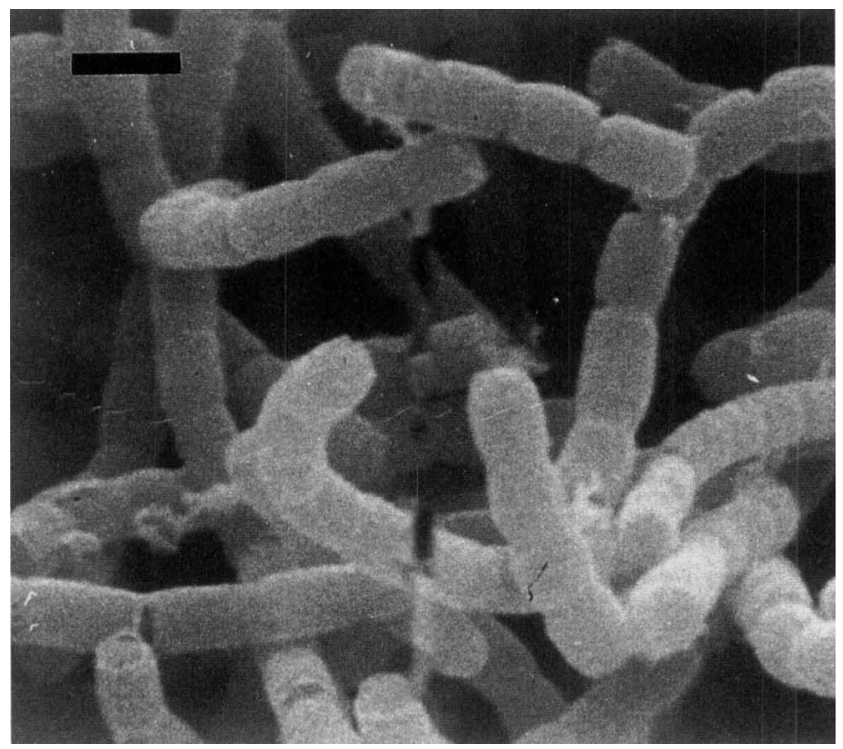

FIG. 2. Scanning electron micrograph of smooth spores of strain $\mathrm{EF}-87^{\mathrm{T}}$. $\mathrm{Bar}=1 \mu \mathrm{m}$

phologically and physiologically from $S$. albidoflavus, $S$. aureofaciens, $S$. ipomoeae, and $S$. scabies.

The morphological characteristics of the deep-pitted-scabinducing bacteria were similar to those of $S$. acidiscabies, but these bacteria differed in the ability to catabolize sugars and in sensitivity to $\mathrm{pH} 4.5$ (Table 2).

The eight deep-pitted-scab-inducing strains formed a homogeneous group, as shown in a previous study in which the fatty acid and protein profiles of these organisms were compared (5). Furthermore, strain EF-87 ${ }^{\mathrm{T}}$ exhibited DNA reassociation values of $74 \%$ or more with the seven other deep-pitted-scabinducing strains, suggesting that these organisms should be included in the same bacterial species.

The eight deep-pitted-scab-inducing strains described in this study all originated from Québec (Canada), where they were isolated from deep-pitted lesions on potato tubers of different cultivars (Fig. 1). The pathogenicity of these strains has been evaluated on two potato cultivars, Conestoga and Green Mountain (6), and also on carrots, radishes, and parsnips (6a). The strains which we studied induced severe lesions on potato cultivars Conestoga and Green Mountain compared with the symptoms induced by $S$. scabies strains tested under the same conditions. However, they induced only mild symptoms on carrots, radishes, and parsnips. On potatoes, as well as on other crops, more severe symptoms were obtained when the pathogenicity tests were performed in sand (6).

$S$. scabies and $S$. caviscabies have never been isolated from the same tuber. This suggests that the potato scab diseases caused by $S$. scabies and $S$. caviscabies may occur under different environmental conditions. Most $S$. caviscabies strains were isolated from tubers produced in irrigated soils.

Description of Streptomyces caviscabies sp. nov. Streptomyces caviscabies (ca.vi.sca'bies. L. adj. cavus, hollow; L. n. scabies, mange; caviscabies, referring to the ability of the organism to cause deep-pitted scab of potatoes). The eight deep-pittedscab-inducing strains are characterized by a gold mycelium on YME medium and a white mass of spores borne in flexuous chains. The cylindrical, smooth spores are 0.87 to 1.08 by 0.5 to $0.63 \mu \mathrm{m}$ (Fig. 2). The cell walls contain LL-diaminopimelic acid, and the DNA G $+\mathrm{C}$ content is $71 \mathrm{~mol} \%$. The strains do 
not produce melanin. All strains grow on proline or methionine as a sole nitrogen source. They utilize raffinose as a sole carbon source. All strains grow in the presence of $4 \% \mathrm{NaCl}$, $0.1 \%$ phenol, $10 \mathrm{IU}$ of penicillin per $\mathrm{ml}, 10 \mu \mathrm{g}$ of thallous acetate per $\mathrm{ml}$, and $20 \mu \mathrm{g}$ of streptomycin sulfate per $\mathrm{ml}$. Growth is inhibited at pH 4.5 (Table 2). Strain EF-87 (= ATCC 51928) is the type strain of $S$. caviscabies.

\section{ACKNOWLEDGMENTS}

This work was supported by a grant from the Natural Sciences and Engineering Research Council of Canada. C.G. gratefully acknowledges a scholarship from the Fonds pour la formation des chercheurs et l'aide à la recherche du gouvernement du Québec.

We thank P. Magny for help with microscopy, J. Beauchesne for photography, B. Otrysko and R. Brzezinski for critically reading the manuscript, and J. Ristaino for providing $S$. ipomoeae 91-3.

\section{REFERENCES}

1. Archuleta, J. G., and G. D. Easton. 1981. The cause of deep-pitted scab of potatoes. Am. Potato J. 58:385-392.

2. Babcock, M. J., E. C. Eckwall, and J. L. Schottel. 1993. Production and regulation of potato scab-inducing phytotoxins by Streptomyces scabies. J. Gen. Microbiol. 139:1579-1586.

3. Becker, B., M. P. Lechevalier, R. E. Gordon, and H. A. Lechevalier. 1964. Rapid differentiation between Nocardia and Streptomyces by paper chromatography of whole-cell hydrolysates. Appl. Microbiol. 12:421-423.

4. Faucher, E., B. Otrysko, E. Paradis, N. C. Hodge, R. E. Stall, and C. Beaulieu. 1993. Characterization of streptomycetes causing russet scab in Québec. Plant Dis. 77:1217-1220.

5. Faucher, E., E. Paradis, C. Goyer, N. C. Hodge, R. Hogue, R. E. Stall, and C. Beaulieu. 1995. Characterization of streptomycetes causing deep-pitted scab of potato in Québec, Canada. Int. J. Syst. Bacteriol. 45:222-225.

6. Faucher, E., T. Savard, and C. Beaulieu. 1992. Characterization of actinomycetes isolated from common scab lesions on potato tubers. Can. J. Plant Pathol. 14:197-202.

6a.Goyer, C., and C. Beaulieu. Unpublished data.

7. Goyer, C., B. Otrysko, and C. Beaulieu. Taxonomic studies on streptomycetes causing potato common scab: a review. Can. J. Plant Pathol., in press.

8. Hopwood, D. A., M. J. Bibbs, K. F. Chater, T. Kieser, C. J. Bruton, H. M.
Kieser, D. J. Lydiate, C. P. Smith, J. M. Ward, and H. Schrempf. 1985. Genetic manipulation of Streptomyces: a laboratory manual. The John Innes Foundation, Norwich, United Kingdom.

9. King, R. R., and C. H. Lawrence. 1994. Isolation and characterization of thaxtomin-type phytotoxins associated with Streptomyces ipomoeae. J. Agric. Food Chem. 42:1791-1794.

10. King, R. R., C. H. Lawrence, and M. C. Clark. 1991. Correlation of phytotoxin production with pathogenicity of Streptomyces scabies isolates from scab infected potato tubers. Am. Potato J. 68:675-680.

11. Lambert, D. H., and R. Loria. 1989. Streptomyces acidiscabies sp. nov. Int. J. Syst. Bacteriol. 39:393-396.

12. Lambert, D. H., and R. Loria. 1989. Streptomyces scabies sp. nov., nom. rev. Int. J. Syst. Bacteriol. 39:387-392.

13. Locci, R. 1989. Streptomycetes and related genera, p. 2451-2508. In S. T. Williams, M. E. Sharpe, and J. G. Holt (ed.), Bergey's manual of systematic bacteriology, vol. 4. Williams and Wilkins, Baltimore.

14. Loria, R., R. A. Bukhalid, R. A. Creath, R. H. Leiner, M. Olivier, and J. C. Steffens. 1995. Differential production of thaxtomins by Streptomyces species in vitro. Phytopathology 85:537-541.

15. Paradis, E., C. Goyer, N. C. Hodge, R. Hogue, R. E. Stall, and C. Beaulieu. 1994. Fatty acid and protein profiles of Streptomyces scabies strains isolated in eastern Canada. Int. J. Syst. Bacteriol. 44:561-564.

16. Pridham, T. G., P. Anderson, C. Foley, L. A. Lindenfelser, C. W. Hessetine, and R. G. Benedict. 1956-57. A selection of media for maintenance and taxonomic study of streptomycetes. Antibiot. Annu. 1957-57:947-953.

17. Sambrook, J., E. F. Fritsch, and T. Maniatis. 1989. Molecular cloning: a laboratory manual, 2nd ed. Cold Spring Harbor Laboratory Press, Cold Spring Harbor, N.Y.

18. Shirling, E. B., and D. Gottlieb. 1966. Methods for characterization of Streptomyces species. Int. J. Syst. Bacteriol. 16:313-340.

19. Stall, R. E., C. Beaulieu, D. Egel, N. C. Hodge, R. P. Leite, G. V. Minsavage, H. Bouzar, J. B. Jones, A. M. Alvarez, and A. A. Benedict. 1994. Two genetically diverse groups of strains are included in Xanthomonas campestris pv. vesicatoria. Int. J. Syst. Bacteriol. 44:47-53.

20. Staneck, J. L., and G. D. Roberts. 1974. Simplified approach to identification of aerobic actinomycetes by thin-layer chromatography. Appl. Microbiol. 28: $226-231$.

21. Ulitzur, S. 1972. Rapid determination of DNA base composition by ultraviolet spectroscopy. Biochim. Biophys. Acta 272:1-11.

22. Williams, S. T., M. Goodfellow, G. Alderson, E. M. H. Wellington, P. H. A. Sneath, and M. J. Sackin. 1983. Numerical classification of Streptomyces and related genera. J. Gen. Microbiol. 129:1743-1813. 